\title{
Neither Agree or Disagree
}

National Cancer Institute

\section{Source}

National Cancer Institute. Neither Agree or Disagree. NCI Thesaurus. Code C103804.

Without concurrence or opposition. 